Article

\title{
What Governs Tree Harvesting in Community Forestry-Regulatory Instruments or Forest Bureaucrats' Discretion?
}

\author{
Sony Baral * and Harald Vacik \\ Institute of Silviculture, University of Natural Resources and Life Sciences, Vienna, Peter-Jordan-Strasse 82, \\ A-1190 Vienna, Austria; harald.vacik@boku.ac.at \\ * Correspondence: sony.baral@boku.ac.at; Tel.: +43-688-6440-5611
}

Received: 2 September 2018; Accepted: 16 October 2018; Published: 18 October 2018

\begin{abstract}
Community forestry is required to follow a forest management plan (FMP) to ensure sustainable tree harvesting. However, the role of FMPs or forest bureaucrats' discretion in guiding harvesting decisions and the resultant effects has not been explored. This paper investigates tree harvesting practices in community forests $(\mathrm{CF})$ and its effects on forest sustainability, using the forest inventory panel dataset for three consecutive periods (2010, 2013 and 2016), together with qualitative information obtained by key informant interviews and a review of records of the community forest users' group. Harvesting decisions in the CF are largely guided by the decrees or schematic instructions of forest bureaucrats, where the role of the FMP remains highly contested. Whether harvesting decisions should be guided by the prescriptions of the FMP or should be regulated through decrees is a matter of discourse. Forest bureaucrats are arbitrarily reducing harvesting quantities and rarely referring to the prescriptions of the FMP. Consequently, users are compelled to harvest less than half the quantity of trees prescribed in the FMP. Furthermore, they are only allowed to harvest poor quality and dead trees. As a result, the number of good quality trees has increased, while the number of seedlings and saplings has decreased significantly. Although harvesting of saplings and seedlings is a common practice, it is against the provisions of the FMP. Though the current bureaucratic discretion has shown quick short-term effects on the forest stand conditions, the long-term impacts should not be undermined. Our findings will be useful to implementors and policy makers in Nepal and other developing countries with similar circumstances for deciding the tree harvesting. We argue for a rational approach in designing harvesting prescriptions and complying with them rather than regulating harvesting practices through guidelines, circulars and bureaucratic discretion.
\end{abstract}

Keywords: harvesting; forest management plan; sustainability; regulatory instruments; forest condition

\section{Introduction}

After the nationalization of forests in the 1950s, a sort of anarchy prevailed in the forestry sector in Nepal, which encouraged illegal logging, deforestation and forest encroachment, particularly in the Terai region [1]. The failure of nationalization of forests led to massive deforestation during the second half of the twentieth century and paved the way for community forestry in the country $[2,3]$. Under the concept of community forestry, the government transferred the responsibility for forest management to local communities through participatory forestry approaches [4]. Nepal is the first country devolving forest management from the authorities to local communities for conserving forest resources, which has attracted worldwide attention [5]. Over four decades, community forest user groups (CFUGs) in Nepal have made intensive efforts to improve degraded forests [6-8] and provide 
benefits to nearly 2.5 million households, which comprise more than 35\% of the country's population. Approximately $27.5 \%$ of the country's total forest area is managed by CFUGs [9] and a national survey indicates that the overall forest area has reached $44 \%$ of the country's area [10], a $20 \%$ increase over the previous two decades [9]. Although forest cover has increased [6,8,11], the long-term aspects of forest sustainability have received little attention. The oft-quoted slogan, "rukh ropaun ban jogaun" (let's plant trees, and conserve forests), has successfully contributed to the conservation of forests, but it has completely jeopardized the potential economic utilization of forest resources [12].

According to the Federation of Forest Based Industry and Trade Nepal, around 29.3 million cubic feet of timber was imported into the country from East Asian and other countries in 2015, while 37.6 million cubic feet of timber decayed or were not utilized in the country's forests [13]. The forest bureaucrats responsible for forest management prescriptions are reluctant to allow the harvesting of trees, due to the mandatory requirement for complying with various policies and regulations. The Community Forest Directives 1995 (revised 2014) and Community Forestry Inventory Guidelines 2004, adopted by the Ministry of Forests and Soil Conservation (MFSC), made it mandatory for CFUGs to prepare forest management plans (FMP). CFUGs prepare the FMPs with the support of forest technicians, where forest bureaucrats define management prescriptions, including the allowable annual harvest quantity [14]. The FMP, in essence, is a vehicle to regulate management activities [15,16] and assure the implementation of regulatory instruments on the ground [15]. However, inventory data and analysis results are often misinterpreted in preparing the FMPs according to bureaucratic requirements [16]. Consequently, forest management practices in community forests (CFs) are being dominated by forest bureaucrats [15].

With the existing FMPs, regulating sustainable harvest in uneven-aged forests is difficult and challenging, as they also do not examine the contextual role of management planning adequately. Gurung et al. [17] studied the role of FMP in improving forest conditions and found that forest management activities were rarely carried out according to FMP. Additionally, the formulated rules of the FMP restricted the access to forest products. There are several indications that the conditions of the forest resources in CFs are improving [18,19], but the role of forest management prescriptions is not well known [16]. Though several researchers question the role of FMPs in implementing harvest decisions $[15,16,20,21]$, the short- to mid-term effects on forest stand conditions are poorly understood. For example, preventing the felling of good quality green trees and promoting the extraction of 4D (dead, dying, diseased and decayed) trees only might have improved the condition of the forests but negatively affected the benefits of CFUGs [22]. However, there is a lack of periodic data from permanent plots in CFs to estimate the long-term effects of such harvesting practices [23].

Many of the problems in the management of uneven-aged forests in Nepal are also related to the fact that only the stand volume has been considered in the regulation of uneven-aged stands for years, ignoring changes in diameter classes. Natural regeneration is largely ignored, and harvesting is confined to the extraction of logs, ignoring the recent stand development. Recent statistics even show that forest conditions are not improving significantly [10]. DFRS [10] indicates that, although the

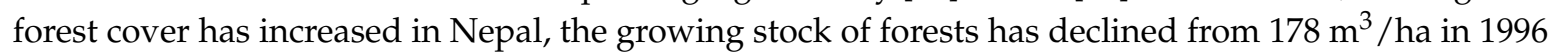
to $164.76 \mathrm{~m}^{3} /$ ha in 2015 [10]. This apparently raises a question: do regulatory instruments including FMPs, or forest bureaucrats, determine the harvesting practices in Nepal's CFs? We hypothesize that discretion of forest bureaucrats overshadows the role of FMP in tree harvesting. Therefore, this paper analyses the effect of tree harvesting practices in the context of existing formal and informal instruments of CF management in Nepal. More specifically, we:

- $\quad$ investigate the tree harvesting practices in selected case studies, focusing on the compliance of regulatory instruments, including FMP, and on what guides harvesting decisions;

- compare the quantity of harvest of economically valuable species (Shorea robusta Gaertn. f. hereafter S. robusta) with that of other species;

- quantify the effects of harvesting practices on tree quality, health, regeneration and stand composition and appraise the reasons for the observed changes; and 
- appraise whether it is the FMP or forest bureaucrats who determine the number of trees to be harvested.

\section{Regulatory Instruments Render Tree Harvesting: An Analysis}

After the restoration of democracy in Nepal in 1990, the Forest Act 1993, as the first democratic movement was enacted as a principal legal instrument to promote community forestry in the country. This law established local people's rights over forest resources [18] and was regarded as a landmark instrument in Nepal's forest management. Thereafter, the inventory-based FMP was introduced in the early 2000s, where a certain portion of increment was allowed to be harvested by type of species (see Community Forestry Inventory Guidelines 2000). This type of harvesting existed until the amendment of the guidelines in 2004, which addressed the shortcomings in traditional forest management. During the same time period, Community Forest Guideline 1995 was amended in 2001, which institutionalized inventory-based management plan. The guidelines further expanded the role of forest technicians in the CFs and prescribed the templates of FMP. The plan consists of the technical aspects of forestry such as growing stock, block divisions, biomass, timber volume, and annual harvesting yields along with the harvesting and sale procedures [21]. The Forest Inventory Guidelines 2004 introduced annual increment of forest stand by forest condition and species, and it ranges between $1 \%$ and $5 \%$ of the growing stock volume. This resulted in the harvesting of economically valuable green trees, leading to deforestation [1]. Consequently, the government banned green harvesting of timber all over the country in 2011 for about a year, aiming to control forest deforestation. In 2012, the government issued a decree for green harvesting with restrictive provisions. According to this provision, the growing stock should be aligned within the threshold of a national average of $178 \mathrm{~m}^{3}$ per ha and the harvested amount should be between 1 and $2 \mathrm{~m}^{3}$ per ha irrespective of the forest condition (Table 1). This decision seemingly led to a reduction in tree harvesting quantity [21,22]. The main reason for reducing the quantity of harvest was sporadic cases of illegal timber harvesting across the country [24]. In addition, the government issued the Community Forest Product Collection and Sale Directives 2014 [25], which expanded the bureaucratic involvement in CFs. The regulatory instruments introduced were often not understandable by CFUGs and the local technical personnel [20]. In addition, a Silviculture-based Forest Management emphasis was introduced when the Scientific Forest Management Guideline was introduced in 2014.

Table 1. Key features and implications for harvesting found in major regulatory policy documents in Nepal.

\begin{tabular}{|c|c|c|}
\hline Policy Document(s) & Key Features & Implications \\
\hline $\begin{array}{l}\text { Forest Act } 1993 \text { \& Forest } \\
\quad \text { Regulation } 1995\end{array}$ & $\begin{array}{l}\text { A national forest handed over to a local } \\
\text { community for conservation, utilization } \\
\text { \& management according to the forest } \\
\text { management plan (FMP) prepared by } \\
\text { community forest user group (CFUG) } \\
\text { and approved by the District Forest } \\
\text { Officer (DFO) }\end{array}$ & $\begin{array}{l}\text { The users can sustainably harvest forest } \\
\text { products within the quantity specified } \\
\text { in the FMP }\end{array}$ \\
\hline $\begin{array}{c}\text { Forest Products } \\
\text { (Timber/Fuelwood) Collection, } \\
\text { Sale and Distribution } \\
\text { Directives } 2000\end{array}$ & It prescribed for harvesting & $\begin{array}{c}\text { The user can follow prescribed } \\
\text { procedures to be followed } \\
\text { during harvesting }\end{array}$ \\
\hline $\begin{array}{l}\text { Community Forestry } \\
\text { Guidelines, } 2000\end{array}$ & $\begin{array}{l}\text { Estimating growing stock and allowable } \\
\text { annual harvest }(\mathrm{AAH})\end{array}$ & $\begin{array}{c}\text { Provisions for tree harvesting in relation } \\
\text { to increment. It remains silent on the } \\
\text { quality of tree to harvest. } \\
\text { The inventory-based provisions were } \\
\text { enforced at the FMP preparation } \\
\text { stage only }\end{array}$ \\
\hline
\end{tabular}


Table 1. Cont.

\begin{tabular}{|c|c|c|}
\hline Policy Document(s) & Key Features & Implications \\
\hline $\begin{array}{l}\text { “Plant Holiday" declared-MFSC, } \\
\text { (21 May 2010) }\end{array}$ & $\begin{array}{c}\text { Restriction on the harvesting of timber } \\
\text { throughout the country especially } \\
\text { in Terai }\end{array}$ & $\begin{array}{l}\text { The forest could not be harvested } \\
\text { according to FMP. The quantity of the } \\
\text { harvest reduced substantially }\end{array}$ \\
\hline Circular-MFSC, 2 December 2011 & $\begin{array}{c}\text { The decision to harvest fallen trees only } \\
\text { within the AAH }\end{array}$ & $\begin{array}{l}\text { Discouraged harvesting of green trees, } \\
\text { \& promote the } 4 \mathrm{D} \text { collection, causes } \\
\text { improvement in forest quality }\end{array}$ \\
\hline \multirow{4}{*}{ Circular-MFSC, 6 March 2012} & $\begin{array}{l}\text { While estimating AAH, growing stock } \\
\text { volume of the forest should not exceed } \\
178 \mathrm{~m}^{3} \text { per ha }\end{array}$ & $\begin{array}{l}\text { The blanket approach undermines the } \\
\text { provisions of continuous harvesting in } \\
\text { uneven-aged forests, \& encourages } \\
\text { manipulation of the growing stock } \\
\text { volume to align with the } \\
\text { national average }\end{array}$ \\
\hline & $\begin{array}{l}\text { Annual harvesting is limited between } 1 \\
\text { to } 2 \mathrm{~m}^{3} \text { per ha of the forest, which is } \\
\text { nearly } 1 \% \text { of growing stock volume } \\
\text { (assuming } 178 \mathrm{~m}^{3} \text { per ha) }\end{array}$ & \\
\hline & $\begin{array}{l}\text { Except fallen, harvesting restricted for a } \\
\text { year from FMP approval }\end{array}$ & $\begin{array}{l}\text { It undermines the guidelines; inventory } \\
\text { remains silent on species to be harvested } \\
\text { but encourages harvesting " } 4 \mathrm{D} \text { " }\end{array}$ \\
\hline & $\begin{array}{l}\text { The decision to grant approval to CFUG } \\
\text { for harvesting a maximum of } 85 \% \text { of the } \\
\text { approved AAH for internal use only, } \\
\text { and } 60 \% \text { in the case it is also for } \\
\text { external sale }\end{array}$ & \\
\hline $\begin{array}{l}\text { Community Forest Product } \\
\text { Collection and Sale Guideline } 2014\end{array}$ & $\begin{array}{l}\text { Elaborates on processes and procedures } \\
\text { to be followed for harvesting timber } \\
\text { from CFs and sale of it on the market }\end{array}$ & $\begin{array}{l}\text { The guideline expanded bureaucratic } \\
\text { control over harvesting decisions; } \\
\text { involvement of forest bureaucrats is } \\
\text { required on all decisions, i.e., harvesting } \\
\text { and distribution }\end{array}$ \\
\hline $\begin{array}{l}\text { Scientific Forest Management } \\
\text { Guideline, } 2014\end{array}$ & $\begin{array}{l}\text { Forest management planning and } \\
\text { harvesting decisions with the active } \\
\text { involvement of forest bureaucrats }\end{array}$ & $\begin{array}{l}\text { It encourages retaining mother tree } \\
\text { (seed tree) to promote regeneration by } \\
\text { an opening canopy }\end{array}$ \\
\hline
\end{tabular}

Source: [26] Government of Nepal (GoN),1993; [27] GoN, 1995; [28] Department of Forests (DoF), 2000; [29] DoF, 2004, [30] DoF, 2012, [31] DoF, 2014 and [25] GoN, 2014.

\section{Materials and Methods}

\subsection{Study Area}

Kankali CF, a natural forest located in Khairani Municipality, Chitwan District, in the low-lying Terai plains in Province 3 of Nepal (Figure 1) was selected for this study. The forest lies at $27.65^{\circ} \mathrm{N}, 84.57^{\circ} \mathrm{E}$ and between 220 and $580 \mathrm{~m}$ above mean sea level. It is dominated by tropical S. robusta, Semecarpus anacardium L.f., Holarrhena pubescens Wall., Terminalia alata Heyne ex Roth., and Dalbergia sissoo Roxb. ex DC. For the management purpose, the forest is divided into five blocks, each between 99.8 ha and 191.4 ha in size.

The site was selected based on the existence of panel forest inventory data for 2010 and 2013, and a similar protocol was used to collect data in 2016.

The community comprising 2065 households residing in 546.7 ha of land manages the 749.2 ha of forest with both long- and short-term objectives. The long-term objectives (generally realized beyond the FMP) are to fulfill the needs of the community regarding forest products, maintain the forest ecosystem, enhance biodiversity through scientific forest management, and improve the livelihoods of users [32]. Likewise, the short-term objectives (to be achieved within the FMP duration) are to ensure a continuous supply of forest products, control forest encroachment, erosion, and grazing, and promote income generation activities [32]. The forest was handed over to the local communities in 1995. 


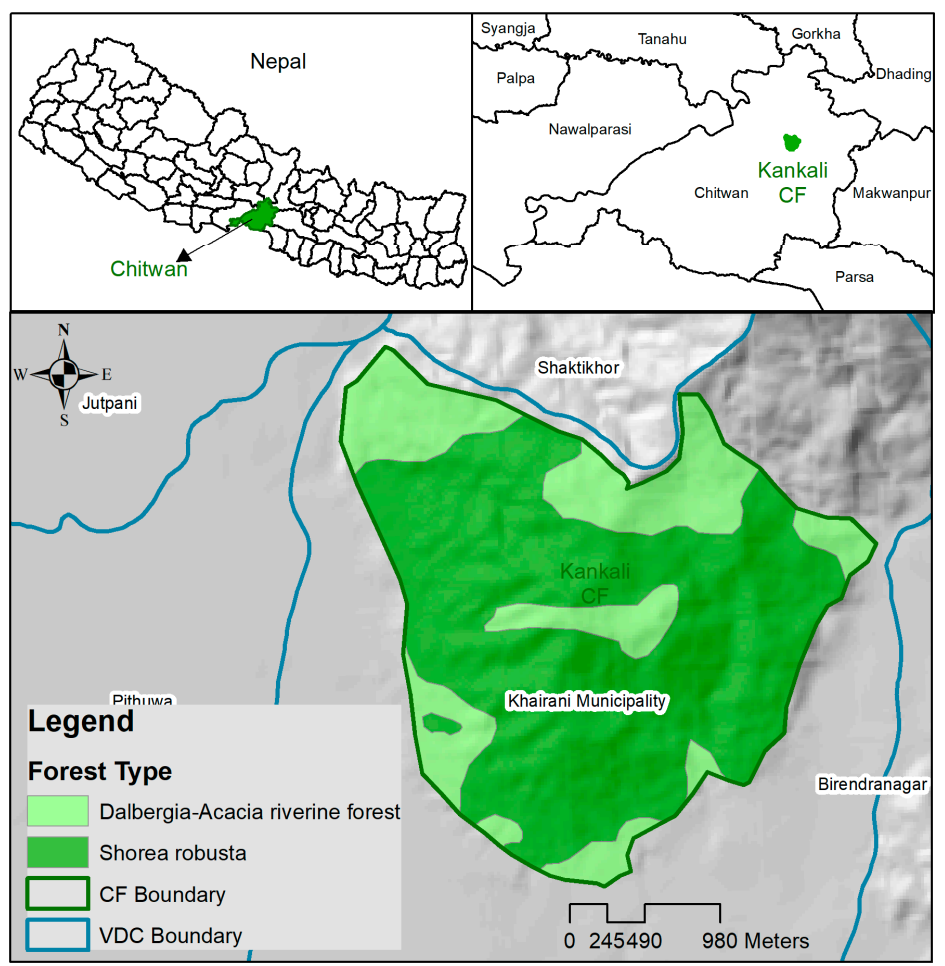

Figure 1. Study area in central Nepal showing different forest types and Village Development Committee boundary.

\subsection{Data Collection}

The study used a case study approach to understand the harvesting practices and their effects on forest management. Field data were collected between August 2016 and June 2018. The policy documents related to harvesting, since the initiation of community forestry, was also thoroughly reviewed.

Permanent plots were laid according to the stratified random sampling method described by Meilby et al. [23] using the coffee-house approach suggested by Müller [33] where the first plot was selected randomly, and the successive plots were laid to maximize the minimum distance to neighbouring plots [34]. The inventory data were collected from 57 permanent plots, established by "The Community Based Natural Forest Management in the Himalaya (ComForM) project", jointly implemented by Institute of Forestry, Tribhuvan University, Department of Forest Research and Survey, Government of Nepal, and Danish Centre for Forest, Landscape and Planning, University of Copenhagen from 2003 to 2014. The study collated existing inventory data of 2010 and 2013, and conducted an additional inventory in 2016, following the same protocol. The forest inventory in autumn 2016 followed the plot design of [23] including three nested subplots. Table 2 shows the size of the plots for the different tree categories measured. Parameters measured included tree diameter at breast height, height, canopy, health, quality and regeneration condition.

Table 2. Categories of trees and plot size used.

\begin{tabular}{ccc}
\hline Category & Diameter & Plot Size \\
\hline Seedlings & $<2.0 \mathrm{~cm}$ & $(1 \times 1) \mathrm{m}^{2}$ \\
Saplings & $2.0-3.9 \mathrm{~cm}$ & $(5 \times 5) \mathrm{m}^{2}$ \\
Established Saplings & $4.0-9.9 \mathrm{~cm}$ & $(10 \times 15) \mathrm{m}^{2}$ \\
Trees & $\geq 10 \mathrm{~cm}$ & $(20 \times 25) \mathrm{m}^{2}$ \\
\hline
\end{tabular}

Source: ComForM Manual. 
In addition, we used snowball sampling method to identify key informants (altogether 21) who were consulted for information on decision making and actual practices tree harvesting. The key informants constituted of past and present executive committee members (4), forest guards (4), forest bureaucrats (4), persons involved in harvesting operations (4) and the CFUG staff (5). The aim of such consultations was to understand the actual harvesting practices in compliance with the prescriptions of the FMP, and the role of forest bureaucrats. Similarly, the criteria (four D trees, deformed trees, canopy opening, species competition, economic importance and diameter size) for selection of trees to be harvested were developed prior to executing the ranking exercises jointly with key informants. The key informants for the ranking constituted of (nine) DFO staff and (11) users. They were asked individually to rank each criterion on a scale of 1 to 7 , where is 1 is the least preference and 7 is the highest preference. The information collected was validated and triangulated through interactions with the different groups of key informants to get an in-depth understanding of the context.

\subsection{Data Analysis}

The inventory data were analyzed by stratifying them based on species $S$. robusta versus other Terai hardwood species (hereafter, other species). Furthermore, trees were stratified based on diameter in classes: seedlings, saplings, poles, and trees. Data were analyzed focusing on the species, type and size of the trees removed from the forest. Prescribed harvest amounts were computed from the FMP and official records of the CFUG, while actual harvest was estimated based on the forest inventory results between the two periods 2010-2013 and 2013-2016. Basal area $\left(\mathrm{m}^{2} / \mathrm{ha}\right)$ differences in the frequency and occurrence of tree species were analyzed by species type. Stand density/composition was analyzed by comparing the distribution of tree diameter classes and canopy percentages. The canopy cover was grouped into three categories: poor density (10\%-39.9\%), moderate density $(40 \%-69.9 \%)$ and high density $(>70 \%)$. A correlation test was done to assess the relationship between canopy closure and regeneration number.

All measured trees were further classified based on their health and quality. According to their health, trees were grouped into three categories: (i) healthy (live trees with no sign of reduced vigour), (ii) weak (live trees showing signs of reduced vigour) and (iii) dying (live trees showing clear signs of dying). Similarly, trees were classified into three categories based on quality: (i) high quality trees (live trees with good form, high probability for a saw log with a length of at least six meters, $<4 \%$ of cull volume in the section from the stump to the upper limit of saw log of merchantable quality), (ii) sawn timber (a log is considered merchantable when $\geq 50 \%$ is perfectly straight) and (iii) cull trees (live trees with poor form, indications of injury or decay). The grouped data of quality and health were analyzed in percentage and presented in a histogram.

In addition, content analysis was also performed for reviewing written documents such as: forest records and minutes, forest inventory results, the FMP, forest products extraction records from the user committee and the Community Forest Inventory Guidelines, 2004. The analysis mostly focused on indications for deviations of the recorded and actual harvesting. The review of the FMP allowed identifying provisions given for harvesting and the basis for prescriptions. The content analysis together with the findings of the interviews of the key informants supported the overall comparison of the differences between the prescriptions and the actual practices.

\section{Results}

\subsection{Harvesting Practices}

The forest is divided into five blocks for its management. Harvesting is carried out based on the annual increment of the growing stock volume. The FMP has a provision for harvesting forest products, especially timber and fuelwood (Table 3). According to the FMP, users can harvest " $4 \mathrm{D}$ " tree throughout the forest and the prescribed volume of green trees from a specified block. However, 
information on where and how to harvest is missing in the FMP. One of the CF executive members explained about the harvesting of timber in practices:

"The decision on the harvesting of the tree is taken by forest bureaucrats. The harvesting team (forest guards and crew) mainly focuses on finishing the task and doesn't take any precautions for protecting seedlings and saplings. Every other year, new forest bureaucrats come up with their own ideas and impose them based on their own interests or government's ad hoc decisions. This creates confusions and delays in harvesting operations" (Field note, 2017).

Table 3. Observed deviations of forest management practices with reference to the FMP.

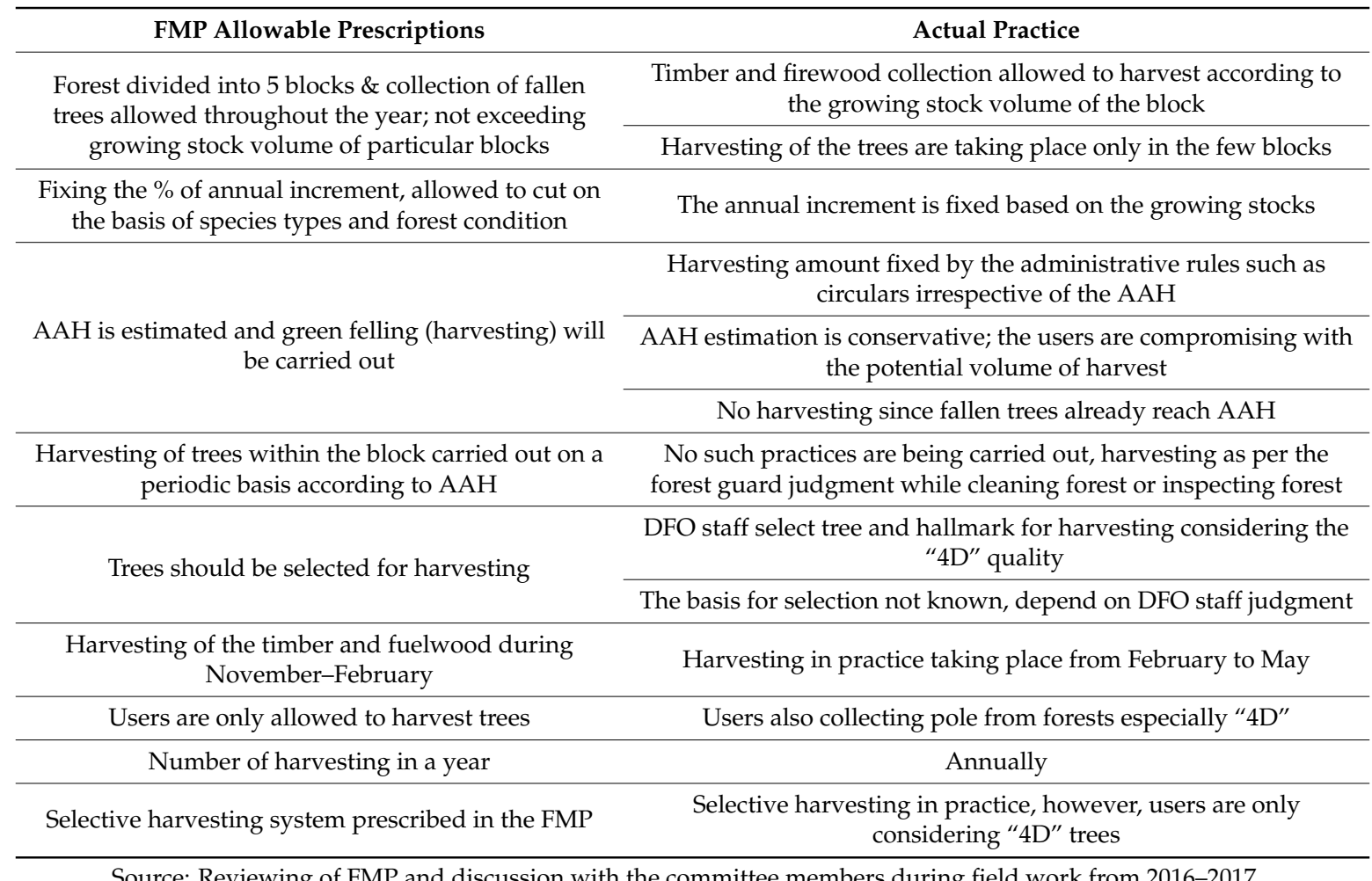

Harvesting is regarded as a major activity in forest management. The CFUG was involved in management activities before the "Community Forest Product Collection and Trade Directive 2014" was enforced [22]. After the directive came into force, the responsibility of forest management decision rested on the Forest bureaucrats. In the usual practice, the CFUGs collect information regarding the amount of required timber and submitted a request to the DFO office. The forest bureaucrats decide where to harvest (see Table 3) and users mark the trees to be harvested. Some of the users informed us that they were not in a condition to take harvest decisions themselves; so, they followed the instruction of the DFO office. Users, however, are not satisfied with the decisions and procedures, as often they are only allowed to harvest " $4 \mathrm{D}$ " trees. The users of the studied CF presented similar views, and thus our inventory results had a minor role in decision making.

The AAH is estimated based on the inventory results, but green trees, especially small pole-sized trees, are also harvested as needed, although the FMP has restricted this kind of harvesting. The FMP mentions that trees should be selected considering tree competition, diameter class, and tree conditions. But these criteria are not considered while selecting trees for harvesting. The amount to be harvested is mainly guided by administrative rules such as circulars. Moreover, the amount of fallen trees often exceeds the AAH. A past executive member of the CFUG, who was involved in harvesting operations for nearly two decades said: 
Harvesting is guided not by the FMP, but by the discretion of the forest bureaucrats', FMP is like an "elephant's tusk" only an adornment but not of use (Field note, 2017).

The FMP prescribes that harvesting operations should be conducted during November-February; however, such activities do not take place as prescribed. The FMP states that the general assembly of users should submit an application to the DFO to harvest a prescribed quantity of timber and fuel wood. The approval of the application and the marking of trees takes a considerably long time. As a result, trees are harvested during February and March, mainly because of the complicated and lengthy administrative procedures of getting a permit. For example, the community studied in this research submitted an application to the DFO in January 2015 but the harvesting took place several weeks later, in March 2015.

Based on the prescriptions in the FMP a number of harvesting activities are to be carried out within selected blocks. However, the activities couldn't take place due to new decrees and policies. Therefore, the recommendations in the FMP on harvesting practices are inadequate.

During our inventory, we asked some forest users and newly recruited forest bureaucrats "how decisions concerning harvesting were taken". The forest users instead asked us to enquire with the forest bureaucrats, one of whom responded that,

"the government allows harvesting of the annual increment of $1 \%$ of the growing stock volume, where only $60 \%$ of the increment can be harvested for external use and $80 \%$ for internal use. Only $4 \mathrm{D}$ trees can be harvested. As this CF had a lot of fallen trees, harvesting covered only the collection of fallen trees that got distributed to users within the volume allowed by a decree".

When asked further about the use of the FMP on harvesting decisions, he answered:

"I don't believe in the inventory results of this CF, especially the growing stock volume. We are bound to follow many regulations on harvesting; so, the FMP has little role in harvesting." (Field note, 2017).

According to the FMP, trees should be selected considering the $4 \mathrm{D}$ criterion; however, species competition and other silvicultural characteristics remain of less priority. Figure 2 shows that both DFO and users equally prefer harvesting $4 \mathrm{D}$ trees. In addition, users give high preference to diameter size and deformation of trees. They are not aware of technical considerations, such as economic importance, species competition, canopy opening, that district forest bureaucrats consider. From field observations, we found that the management focused on producing lumber which can be used for fuelwood in the future. The individual crop trees face a high competition in the forest and there is no intention to reduce the competition. One of the users admitted that the provisions in the FMP and its approval are merely for authentication and have nothing to do with forest inventory results. A user involved in harvesting operations said:

"During harvesting, we generally select standing dead trees as DFO staff does not allow us to harvest green trees while $4 D$ trees are in the forest." (Field note, 2017). 


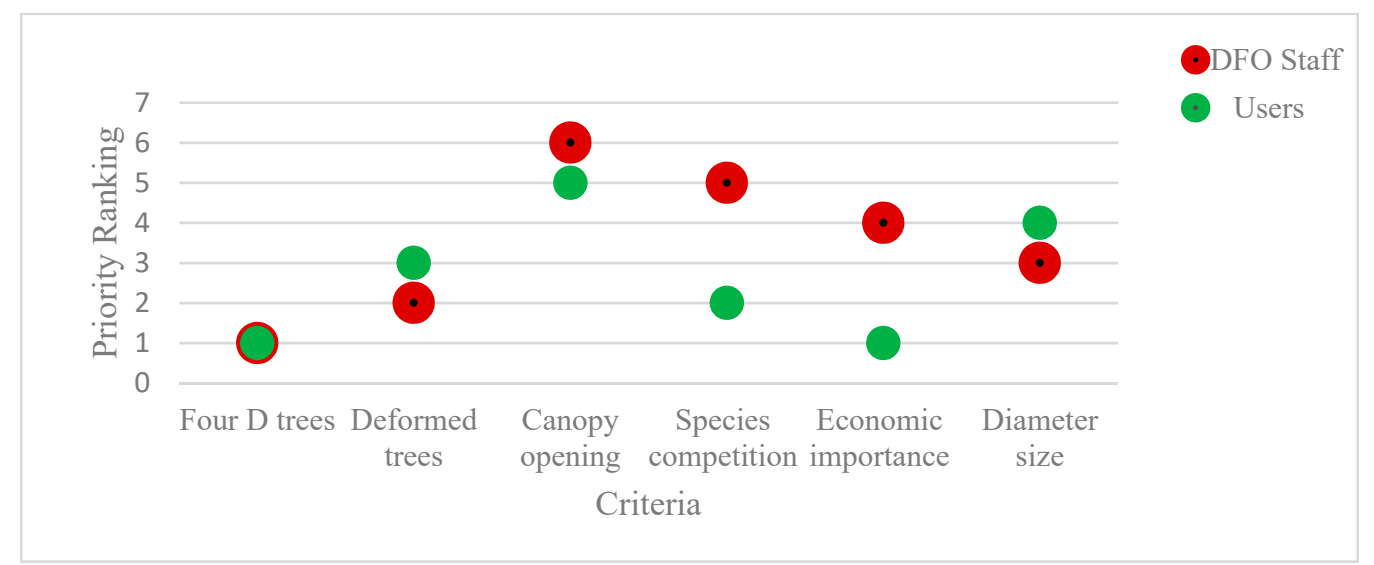

Figure 2. Priority ranking of DFO staff and users in selecting trees for harvesting. Source: Users and DFO officials of Kankali CFUG, Chitwan (2017).

\subsection{Comparing Actual and Allowable Harvesting Quantities}

From a review of the last two periods, I (2010-2013) and II (2013-2016) of the FMP, it was found that the growing stock of the forest in the previous FMP (2010-2013) was $146 \mathrm{~m}^{3} / \mathrm{ha}$, while it increased to $170 \mathrm{~m}^{3} /$ ha in the current FMP (2013-2016). In the previous FMP, the increment of the growing stock was estimated to be 3.0\%, while the current FMP estimates 1\%. The recent provision contradicts the Community Forestry Inventory Guidelines of 2004. According to the guidelines, the annual increment in the growing stock of the forest ranges from 1\% to $5 \%$ depending on the nature of species (fast, medium and slow growing) and forest conditions (poor, medium and good). Out of the growing stocks $85 \%$ can be harvested. However, the AAH was arbitrarily reduced by the ad hoc circular of the Department of Forests to $178 \mathrm{~m}^{3} /$ ha with an aim of reducing harvest quantity. The circular limits annual growth of forest to maximum $1 \%$, and $60 \%$ of the increment could be harvested. This raises concerns about defining the limit of sustainable harvesting and the role of inventory. For instance, the chairperson of the CF stated:

"We could hardly distinguish any difference between the harvesting practices during two periods, but the prescribed amount has reduced drastically between the two FMPs; the only difference we observed was in the quantity" (Field note, 2018).

Figure 3 presents the AAH of the growing stock and the actual harvest, suggesting that the users were not harvesting what they were actually allowed in the FMP. The low harvest rates were often caused by delays in obtaining permits from forest bureaucrats (in 2007) or by the ad hoc decisions of celebrating timber holidays, in 2010 and 2011.

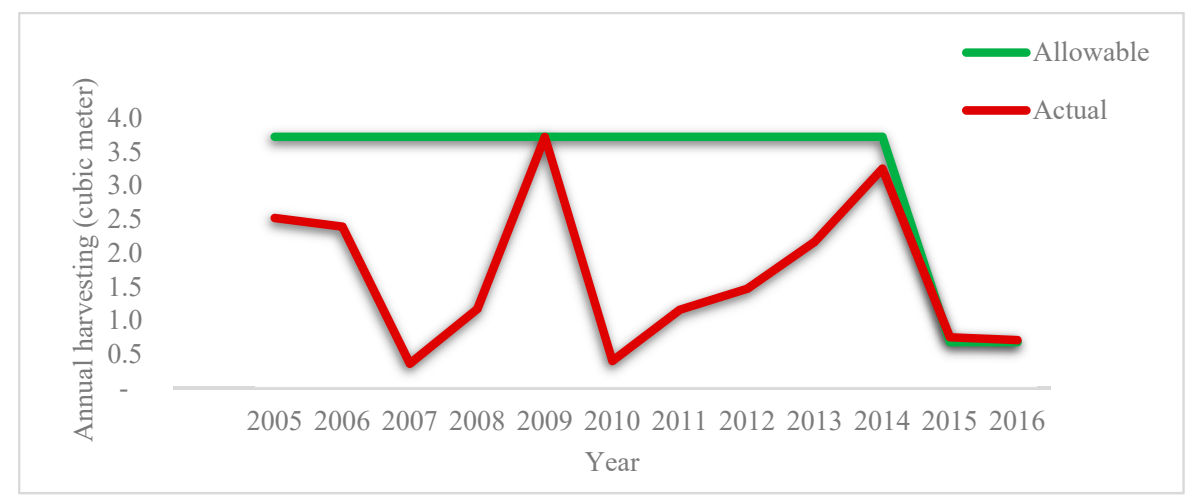

Figure 3. Allowable annual harvest and actual annual harvest in $\mathrm{m}^{3} /$ ha (2005-2016). Source: Data collected from two consecutive FMPs and CFUG records. 
Table 4 shows the recommended harvest rates in the FMP and the actual harvest quantity for the periods I (2010-2013) and II (2013-2016). In the period I, the actual harvest is below the allowable harvest in all blocks while in period II, there exits variation by the blocks. The data indicate that the actual harvest is higher than the allowable harvest in blocks I, II and V while it is lower than allowable in block III and IV in the period II.

Table 4. Block wise allowable harvest in FMP and actual harvest from inventory.

\begin{tabular}{|c|c|c|c|c|c|c|}
\hline \multirow[b]{2}{*}{ Block } & \multicolumn{3}{|c|}{ Harvest (m³/ha per/year) Period I: (2011-2013) } & \multicolumn{3}{|c|}{ Harvest (m³/ha per/year) Period II: (2013-2016) } \\
\hline & $\begin{array}{c}\text { Allowable } \\
\text { (Plan) }\end{array}$ & $\begin{array}{c}\text { Actual } \\
\text { (Inventory) }\end{array}$ & $\Delta$ Change & $\begin{array}{c}\text { Allowable } \\
\text { (Plan) }\end{array}$ & $\begin{array}{c}\text { Actual } \\
\text { (Inventory) }\end{array}$ & $\Delta$ Change \\
\hline I & 2.0 & 0.8 & $(0.6)$ & 1.0 & 2.0 & 1.0 \\
\hline II & 3.3 & 1.9 & $(0.4)$ & 1.6 & 5.0 & 2.1 \\
\hline III & 3.6 & 1.5 & $(0.6)$ & 1.8 & 1.4 & $(0.2)$ \\
\hline IV & 2.3 & 1.1 & $(0.5)$ & 1.1 & 1.1 & $(0.0)$ \\
\hline $\mathrm{V}$ & 1.9 & 1.4 & $(0.2)$ & 0.9 & 1.2 & 0.3 \\
\hline
\end{tabular}

Source: FMP of Kankali CFUG, Chitwan (2016) \& from the inventory of 2016 \& 2017.

Overall, it was found that the actual harvest (from inventory results) in the CF is higher than the reported harvest (CF records), (see Figure 4), but in recent periods the allowable harvest (prescribed in FMP) almost matches the actual harvest. This is mainly because of strict monitoring and supervision of harvesting decisions by forest bureaucrats. Moreover, forest bureaucrats had introduced different thumb rules, such as selecting a poor quality and fallen trees and had also reduced the proportion of annual harvest.

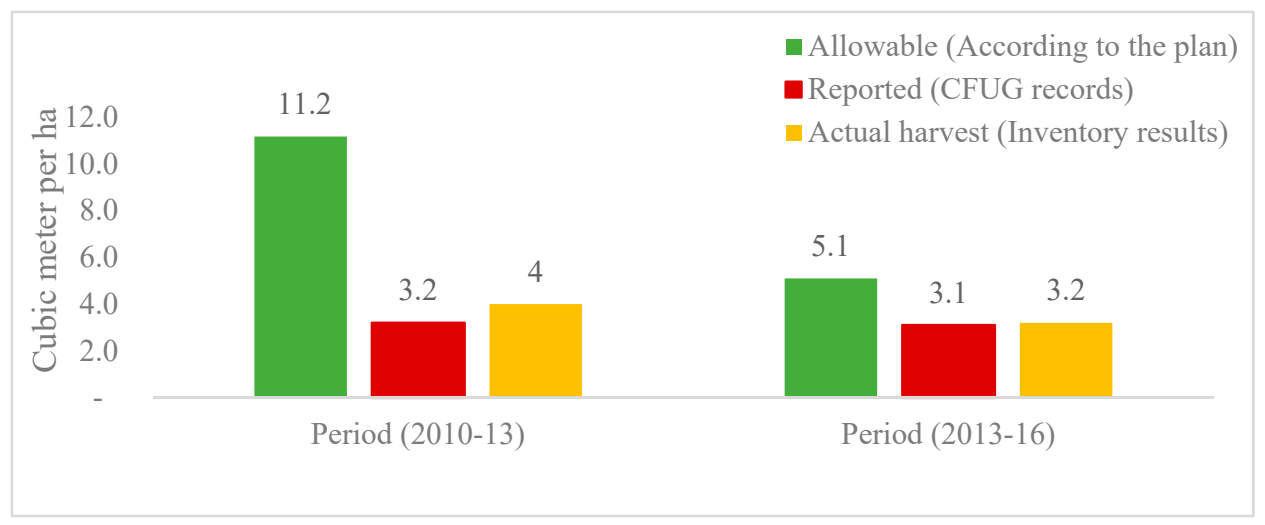

Figure 4. Reported and actual harvest compared to the allowable harvest. Source: Inventory result of 2010, 2013 and 2016, FMP and Inventory recorded.

\subsection{Effect on Forest Condition}

The effects on forest structure were analyzed focusing on (a) changes of regeneration and tree condition and species composition, (b) changes of tree basal area, and (c) changes in tree health and quality.

\subsubsection{Stand Condition and Tree Species Composition}

Table 5 presents a comparison of the stand condition of economically valuable tree species with the other tree species. The results indicate that the number of seedlings had declined from 26,842 in 2010 to 13,421 in 2016 in the case of S. robusta, while that of other species was 6930 in 2010, doubled in 2013 and decreased (9\%) to 6316 in 2016 . However, the number of both saplings and established saplings of all species had declined during the same period. This result also coincides with the correlation of the canopy closure and the total number of natural regenerations. It shows a positive relation (0.48) in 2010 and a negative relation $(-0.10)$ and $(-0.31)$ in 2013 and 2016 respectively. Similarly, in the case 
of saplings, the result shows a weak and negative relation between the canopy cover and the sapling ratio: $(-0.02)$ in 2010, $(-0.03)$ in 2013 and $(-0.02)$ in 2016. However, the correlation is very weak.

Table 5. Stand condition in the CF (n/ha) in different Inventory Period.

\begin{tabular}{ccccccc}
\hline Species Type & \multicolumn{3}{c}{ S. robusta } & \multicolumn{3}{c}{ Others } \\
\hline Diameter Categories & $\mathbf{2 0 1 0}$ & $\mathbf{2 0 1 3}$ & $\mathbf{2 0 1 6}$ & $\mathbf{2 0 1 0}$ & $\mathbf{2 0 1 3}$ & $\mathbf{2 0 1 6}$ \\
\hline Seedling $(>2 \mathrm{~cm})$ & 26,842 & 12,982 & 13,421 & 6930 & 12,456 & 6316 \\
Sapling $(2-3.9 \mathrm{~cm})$ & 337 & 84 & 21 & 225 & 91 & 21 \\
Est. sapling $(4-9.9 \mathrm{~cm})$ & 675 & 504 & 323 & 486 & 336 & 215 \\
Pole $(10-30 \mathrm{~cm})$ & 410.2 & 482.5 & 487.0 & 191.6 & 224.2 & 226.0 \\
Tree $(30-50 \mathrm{~cm})$ & 8.8 & 7.4 & 11.9 & 7.0 & 8.4 & 9.5 \\
Mature Tree $(<50 \mathrm{~cm})$ & 7.4 & 4.2 & 1.1 & 1.4 & 4.6 & 1.1 \\
\hline
\end{tabular}

Source: Inventory result of 2010, 2013 and 2016

Table 5 shows that the number of pole-sized trees increased, while that of mature trees decreased between 2013 and 2016. According to the Scientific Forest Management Guidelines, 2014, at least 15 to 25 mature trees per ha are needed for facilitating natural regeneration. However, the number of trees above $50 \mathrm{~cm}$ diameter is not only less than prescribed but also declined during the three inventory periods and reached nearly one mature tree per ha. While the number of pole trees is increasing, the users are not carrying out any thinning practices prescribed in the FMP. As a result, competition between the poles is increasing, which might affect forest productivity and the capacity for seed production in the long run.

\subsubsection{Tree Basal Area Variation}

Aside from differences in the frequency and occurrence of tree species (Table 5), the basal area $\left(\mathrm{m}^{2} /\right.$ ha) varied by plots and study sites (Figure 5). The basal area of poles decreased from 9.1 to $3.8 \mathrm{~m}^{2}$ / ha for S. robusta and from 4.2 to $2.8 \mathrm{~m}^{2} /$ ha for other species. In the case of mature trees, the basal area decreased from 2.9 to 2.6 for $S$. robusta and remained similar with $0.6 \mathrm{~m}^{2} /$ ha for other species.

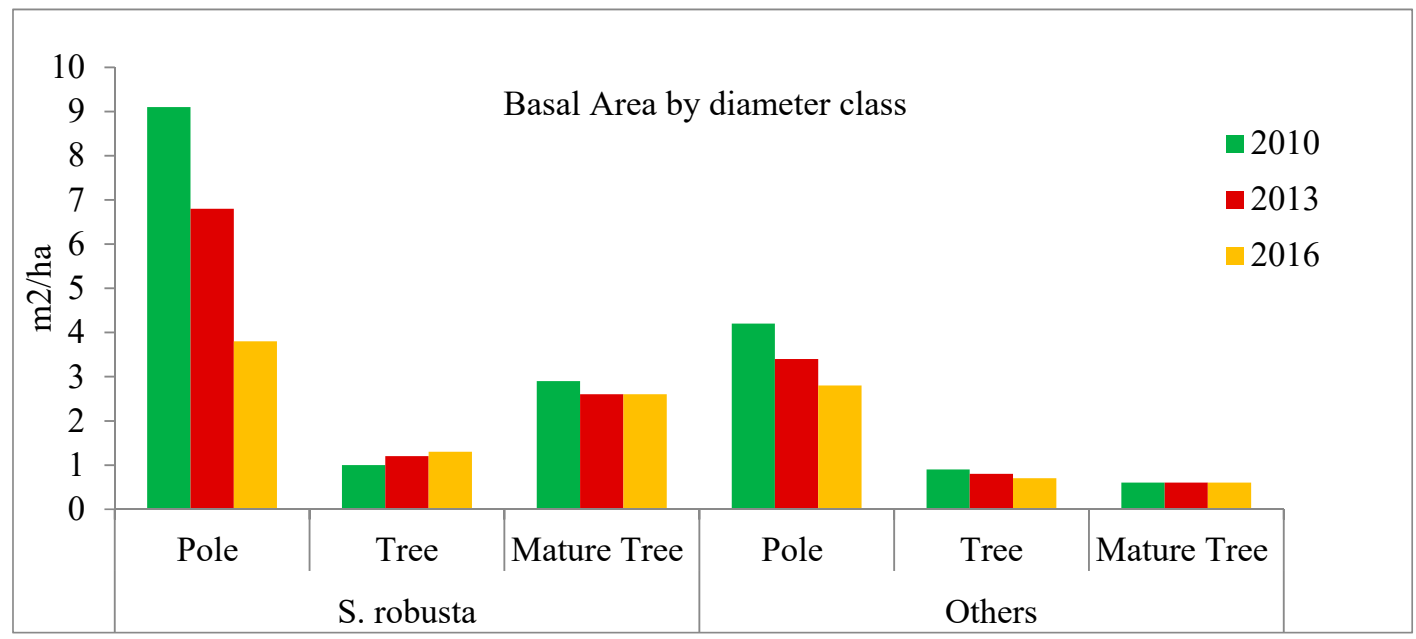

Figure 5. Basal area per ha by species types ( $\left.\mathrm{m}^{2} / \mathrm{ha}\right)$. Source: Inventory of 2010, 2013 and 2016.

\subsubsection{Changes in Tree Health and Quality}

The analysis of the tree health and quality categories (Figure 6) showed that the number of healthy trees increased between 2010 and 2016, i.e., an increment of stems from $85 \%$ to $95 \%$ of stems per hectare. In the case of declining categories, a decrease has been noticed ranging between $3 \%$ to $10 \%$ for both forest types (S. robusta and other categories). Similarly, the quality of log and cull trees improved, while that of sawn trees was decreasing for both forest types. 


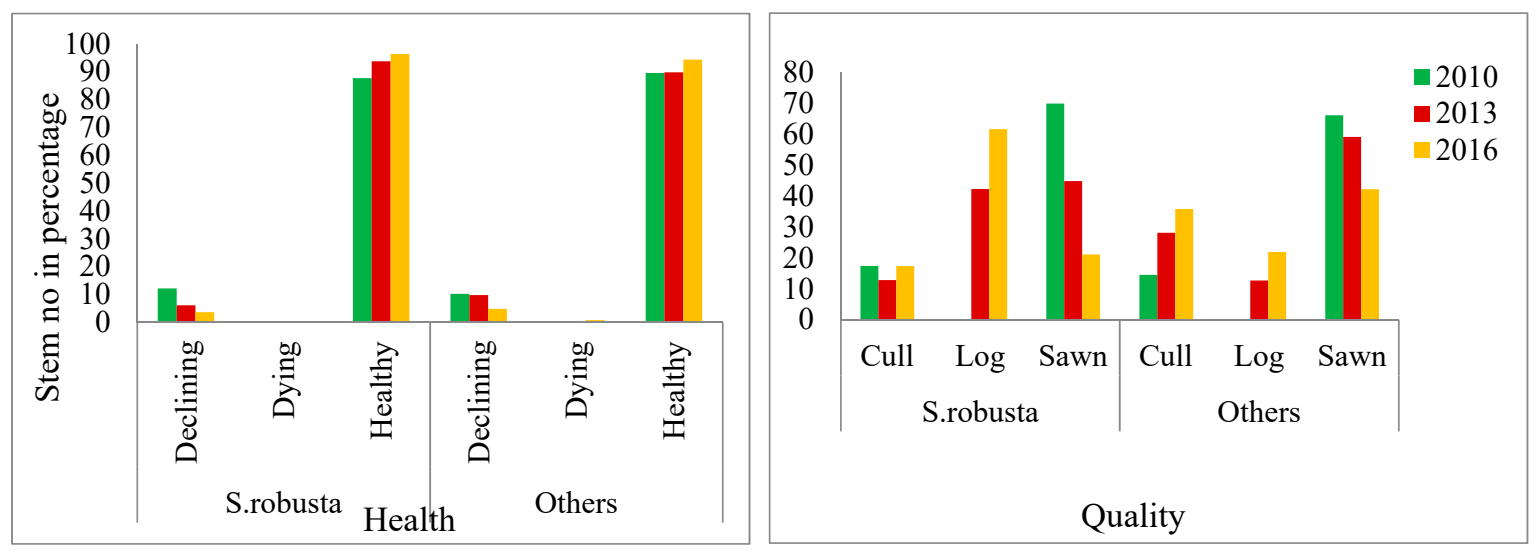

Figure 6. Tree health and quality of S. robusta and other species in percentage.

\section{Discussion}

\subsection{Tree Harvesting Practices-Are They in Compliance with FMPs?}

While investigating the role of the FMP in guiding harvesting practices, the prescribed management practices were found not matching the local practices. The FMP prescriptions rarely guide harvesting; rather, verbal instructions of district forest bureaucrats, such as DFO and rangers, followed by administrative decrees, dictate harvesting decisions; which is also corroborated by [35]. In addition, developing an FMP is quite onerous for the users [36]. Though Nightangle, Ojha et al. [37,38] argued that the technical knowledge of FMP application is important for the management of forest resources in Nepal's CFs, we observed that the FMP has become merely a paper tool to fulfill the criterion of handing over the forest. In recent years, the AAH has been reduced substantially, but without a clear rationale. This apparently raises concern whether the FMP can support harvesting practices of CFUGs. This resonates with the findings of Toft et al. [16], who observe that inventory results are seldom used in preparing FMPs and implementing management activities. A study by Bhattacharya and Basnyat [39], in the western Terai of Nepal, concludes that the prescribed allowable harvesting operations in the FMPs are complex and not specified in detail, which makes it difficult for the users to follow them. Furthermore, Gautam et al. [19] conclude under similar conditions that silvicultural operations are not being practiced according to the FMP. Similarly, the rationale of the block divisions is questionable since users simply collect the AAH volume from the entire forest irrespective of the blocks. Similar findings were reflected in the study of Toft et al. [16], who states that block division is done merely for administrative purposes.

The harvesting prescriptions in the FMP are simply a list of activities appended to the FMP which are to be carried out in a block every year, but the FMP is silent on what, how and where the activities should be carried out. This apparently raises concerns on the usefulness of the described harvesting practices, driven by the aim of opening the forest for penetration of light and providing a favorable environment for regeneration. The reasons for this mismatch can be attributed to the absence of specific knowledge of appropriate harvesting practices of the local communities among the forest bureaucrats, which is also identified by [20], and studies conducted in Nepal, Cambodia, and Vietnam [20,40]. It appears that harvesting operations are one of the basic components of forest management, where the FMP works as a tool to enforce what forest bureaucrats are supposed to classify as correct. Similar findings were presented by Rutt et al. and Toft et al. $[15,16]$ in their studies in the mid-hills of Nepal, and by [41] in Cameroon, where the government continued carrying out timber production, and the management rules and FMP were ignored.

Improvement in the conditions of forest stands are not a result of the implementation of the FMP, but a consequence of other practices within the CF and changes in the economic status of local communities. The current harvesting practices are protection-oriented and conservative, where 
users remove fallen and over-mature trees. While selecting trees, silvicultural characteristics such as species competition are not taken into consideration. Moreover, Subedi et al. [42] conceptualize forest harvesting and silvicultural practices as technical aspects of forestry, often neglecting the engagement of community and stakeholders. This has also impacted the adoption of improved harvesting practices [43].

\subsection{Tree Harvesting Quantity-What Governs It?}

Harvesting of timber is highly unpredictable for long planning periods and the quantity of harvest can vary from year to year. However, the amount of timber harvested in the studied CF has been reduced, despite an increment in the growing stock volume. Our observations reflected that "non-systematic and uneven harvesting of trees resulted in an increment in the growing stock of the forest. Trees are like straight boles without or very less tapering, which is a sign of stiff competition among species, which may retard their growth in the future. Adoption of "protective forest management based on limited use by the MFSC" has resulted in the promulgation of harvesting prescriptions resembling the one size fits all approach, which was also observed in the study of [44], where the FMP and prescriptions are identical.

It seems from the CF records that the total $\mathrm{AAH}$ is more than the reported harvest and the actual harvest estimated from the inventory in periods I and II. The reason behind this is that forest bureaucrats enforced a number of decrees published. Harvesting doesn't correspond with the FMP prescriptions. There is no other specific consideration for tree selection for harvesting, and hence tree selection is often guided by national decrees. There were a series of decrees which changed or limited harvesting in period I, such as the Plant Holiday" declared-by the MFSC on 21 May 2010, which limited green harvesting. Moreover, a circular issued by MFSC on 2 December 2011, allows harvesting of only fallen trees within the AAH limit. Another circular, issued by the MFSC, on 6 March 2012, directs that, while estimating AAH from the forest, the growing stock of the forest should not exceed $178 \mathrm{~m}^{3}$ per ha or that specified in the FMP, whichever lower. The studied case is of Chure (fragile hill); so only $1 \%$ growing stock increment is indicated in the guidelines including FMP. Out of the growing stock $40 \%$ is allowed to be harvested each year, which is a key factor in differentiating the reported and actual harvesting. The main reason for the limited harvesting was the forest officials' discretion rather than the prescriptions of the FMP [20]. The rationale for this recommendation is based on the assumption that Chure, being fragile land mostly of gravel and boulders, where tree growth is low and the land is highly prone to landslides, conservation of forest helps in stabilizing the land. Hence, the quantity of harvest was reduced to be on the safe side. Consequently, Baral et al. [21,22] in studies in Terai and Mid-hills forests of Nepal, conclude that the harvested quantity is far below the annual yield. Cerutti et al. [41] observed a similar situation in a study in Cameroon, where the harvesting was carried out without referring to the FMP. Contrary to our findings, the forest was largely overharvested to maximize revenues, as the benefits of the timber harvest remained largely with the local communities.

\subsection{How Tree Harvesting Decision Affect Tree Quality?}

We observed that local communities preferred economically valuable species and hence emphasized protection of those species. As a result, the dominance (basal area volume) and the number of stems per ha of economically valuable species increased more than those of other species. A similar observation was made by Ojha and Bhattarai [45] in their study in mid-hills of Nepal. Yet another study, Sapkota et al. [46], carried out in the Terai region, concludes that S. robusta is preferred even in the mixed S. robusta forest and priority is given to convert $S$. robusta mixed forest into pure S. robusta forest. The forest is also gradually converting into an S. robusta dominated forest, moving towards a single species forest from a mixed one. This is due to the preference given to the conservation of economically valuable species and discarding low-value species. It shows that management interventions are guided 
by social preferences. Sapkota et al. [46] had similar findings from the Terai region of Nepal, where social preferences guide the species composition and management of the forest.

Generally, we observed that there were no strict rules on harvesting tree species except S. robusta. Government's ad hoc policy decisions, for instance, the blanket ban on timber harvest, oblige bureaucrats to enforce rules to control harvesting of valuable trees, like S. robusta. Our findings resonate with a growing body of literature indicating a high priority given to the conservation of S. robusta in Nepal $[11,45,46]$. Though one of the main objectives of forest management mentioned in the FMP is maintaining forest tree diversity, the dominance of economically valuable species is increasing in the study sites. This is confirmed by a study of six CFUGs in the mid-hills of Nepal [44]. The authors conclude that the current harvesting practices pose a threat to species diversity. Harvesting interventions are difficult without considering the current forest stand structure. In our study, the tree health has improved while the quality has decreased due to high competition between trees, which resonates with the finding of [9], carried out in the western Terai.

\subsection{How Harvesting Practices Affect Stand Condition?}

The number of seedlings, saplings and established saplings of $S$. robusta is decreasing gradually over time, whereas the number of pole trees is increasing. This can be partly caused by the continuous growth of saplings inducing a closed canopy and obstructing the penetration of sunlight $[11,40,46]$. Based on a study in a few Terai districts, Awasthi et al. [11] conclude that canopy opening can improve the regeneration condition in the forest. In addition, the regeneration of the forest in our study is poor because of unrestricted grass collection throughout the year. This might reduce the number of seedlings and saplings despite the presence of open canopy. In theory, the canopy opening should lead to higher regeneration, but biotic influence has a higher role in our case. Harvesting practices also destroyed under-growth due to poor handling of harvested logs while dragging from forests to the $\log$ yard.

\section{Conclusions}

We observed a large gap between the allowable and actual tree harvesting practices in the studied CF. Ideally, harvesting should be carried out according to the FMP; however, the FMP doesn't support harvesting decisions. Harvesting rules are guided by forest bureaucrats' discretions which are based on political coercions rather than economic considerations. The current level of harvest is far below the sustainable amount (as specified in the FMP) which could be harvested from forests. Conservative harvesting practices deteriorate the forest conditions.

On a positive note, current harvesting practices have improved the overall forest conditions, quality and health but at the same time have decreased the number of seedlings and saplings, which is a matter of concern. Although economically valuable species like S. robusta and others had harvesting rates lower than their growth rates, this does not necessarily contribute to sustainable management. Controlled harvesting does not imply the right approach to forest management, rather, harvesting should be guided by management objectives. In recent years, priority has been given to harvesting of poor-quality trees, which has increased the number of quality trees in forests.

Heavily regulated harvesting not only affects the future productive potential of forests but also increases the risk of holding a large number of standing trees in the forest. This may be a serious issue in the long run, which may skew forest population dynamics. Regulatory instruments are important in shaping the boundaries, however, they do not provide sufficient conditions for supporting timber harvesting. Thus, long-term management prescriptions are needed to retain and manage forests. Within CFs, management and harvesting operations are guided by political interests rather than by science; hence, forest management governance is missing. Legally, harvesting following FMP does not necessarily mean "sustainably produced" or "sustainably managed". While the current harvesting practices have generated limited social benefits to the community, the ecological and economic prospects of forestry have been undermined. The optimal level of harvest is not being 
practiced, which is reducing the contribution of forests to economic development. As argued by Baral et al., Hara and Gersond [22,47], the CF has been ecologically sustainable but not economically. Jong et al. [2] concluded that harvesting should ensue all three dimensions of forest sustainability, which is largely ignored in the studied cases.

We conclude that there are inappropriate policy instruments to regulate tree harvesting. There is a need for multidimensional forest management approach to achieve sustainable development. We argue that FMPs should be developed considering the forest conditions and requirements of the CFUGs. They should be simple and applicable rather than adopting them as a ritual. Further, tree harvesting should not be influenced by bureaucratic discretion. Hence, we recommend to follow a pragmatic approach in developing FMPs and complying with them rather than regulating forest management through guidelines or discretion, specially focus should be on (a) building the capacity of CFUGs, (b) developing simple and doable management prescriptions, (c) reducing impact logging, (d) avoiding blanket and ad hoc policy, and (e) developing FMPs considering forest productivity. Moreover, the long-term effects of government circulars on forest sustainability need to be monitored periodically.

Author Contributions: The study was originally designed by S.B. and H.V. S.B. collected primary and secondary data and collated and analyzed them in consultation with H.V. The draft manuscript was developed by S.B. and H.V. contributed to the finalization of the manuscript.

Funding: This research has been financially supported by APPEAR—the Austrian Partnership Programme in Higher Education and Research for Development, (OeAD-GmbH).

Acknowledgments: We are thankful to Institute of Forestry, Pokhara, Nepal for providing time series data of 2010 and 2013. We are also grateful to the forestry officials and community forest user group members of Kankali community forests for openly sharing their information, without which this research would not be possible. Finally, we would like to thank Bijendra Basnyat, IoF for support in data processing and Ganga M. Neupane and enumerators who for their support throughout the field activities with data collection and compilation.

Conflicts of Interest: The authors declare no conflict of interest.

\section{References}

1. Amatya, S.M. Financing for Sustainable Forest Management in Nepal; Indufor Oy: Helsinki, Finland, 2013.

2. Bhattarai, B. Community forest and forest management in Nepal. Am. J. Environ. Prot. 2016, 4, 79-91.

3. De Jong, W.; Pokorny, B.; Katila, P.; Galloway, G.; Pacheco, P. Community forestry and the sustainable development goals: A two-say street. Forests 2018, 9, 331. [CrossRef]

4. Gilmour, D.A.; King, G.C.; Applegate, G.B.; Mohns, B. Silviculture of plantation forest in central Nepal to maximise community benefits. For. Ecol. Manag. 1990, 32, 173-186. [CrossRef]

5. Acharya, K.P. Twenty-four years of community forestry in Nepal. Int. For. Rev. 2002, 4, 149-156. [CrossRef]

6. Gautam, A.P.; Shivakoti, G.P.; Webb, E.L. Forest cover change, physiography, local economy, and institutions in a mountain watershed in Nepal. Environ. Manag. 2004, 33, 48-61. [CrossRef] [PubMed]

7. Ojha, H.; Timsina, N.; Khanal, D. How are forest policy decisions made in Nepal? J. For. Livelihood 2007, 6, $1-17$.

8. Poudel, N.R.; Fuwa, N.; Otsuka, K. The impacts of a community forestry program on forest conditions, management intensity and revenue generation in the Dang district of Nepal. Environ. Dev. Econ. 2015, 20, 259-281. [CrossRef]

9. DoF. Community Forestry Bulletin; Department of Forests (DoF): Kathmandu, Nepal, 2018.

10. DFRS. State of Nepal's Forests; Forest Resource Assessment (FRA) Nepal, Department of Forest Research and Survey (DFRS): Kathmandu, Nepal, 2015.

11. Awasthi, N.; Bhandari, S.K.; Khanal, Y. Does scientific forest management promote plant species diversity and regeneration in Sal (Shorea robusta) forest? A case study from Lumbini collaborative forest, Rupandehi, Nepal. Bank. Janakari 2015, 25, 20-29. [CrossRef]

12. Banjade, M.R. Discourse and discursive practices over timber in Nepal. J. For. Livelihood 2012, 10, 58-73. [CrossRef] 
13. Over 80 Per Cent of Timber Imported from Foreign Countries. The Himalayan Times Daily Newspaper, 20 June 2016. Available online: https:/ / thehimalayantimes.com/kathmandu/80-per-cent-timber-importedforeign-countries / (accessed on 20 June 2016).

14. Shrestha, K.; Amatya, D. Silviculture evolution: A retrospective review to uncover appropriate lessons for forestry advance in Nepal. In Community Forestry in Nepal, Proceedings of Workshops on Community Based Forest Management, Kathmandu, Nepal, 20-22 November 2000; Joint Technical Review Committee: Kathmandu, Nepal, 2000; pp. 69-79.

15. Rutt, R.L.; Chhetri, B.B.K.; Pokharel, R.; Rayamajhi, S.; Tiwari, K.; Treue, T. The scientific framing of forestry decentralization in Nepal. For. Policy Econ. 2015, 60, 50-61. [CrossRef]

16. Toft, M.; Adeyeye, Y.; Lund, J. The use and usefulness of inventory-based management planning to forest management: Evidence from community forestry in Nepal. For. Policy Econ. 2015, 60, 35-49. [CrossRef]

17. Gurung, A.; Bista, R.; Karki, R.; Shrestha, S.; Uprety, D.; Oh, S.E. Community-based forest management and its role in improving forest conditions in Nepal. Small-Scale For. 2013, 12, 377-388. [CrossRef]

18. Pokharel, R. Assessing community forests' condition using variables recommended by local people: A case of Kaski district, Nepal. Bank. Janakari 2005, 15, 40-48. [CrossRef]

19. Gautam, A.P.; Shivakoti, G.P.G.P.; Webb, E.L.E.L. A review of forest policies, institutions, and changes in the resource condition in Nepal. Int. For. Rev. 2004, 6, 136-148. [CrossRef]

20. Gritten, D.; Greijmans, M.; Lewis, S.; Sokchea, T.; Atkinson, J.; Quang, T.; Poudyal, B. An uneven playing field: Regulatory barriers to communities making a living from the timber from their forests—Examples from Cambodia, Nepal and Vietnam. Forests 2015, 6, 3433-3451. [CrossRef]

21. Baral, S.; Vacik, H.; Chettri, B.B.K.; Gauli, K. The pertinent role of forest inventory in making choice of silvicultural operations in community forests of Nepal. Bank. Janakari 2018. [CrossRef]

22. Baral, S.; Gautam, A.P.; Vacik, H. Ecological and economical sustainability assessment of community forest management in Nepal: A reality check. J. Sustain. For. 2018, 37, 820-841. [CrossRef]

23. Meilby, H.; Puri, L.; Christensen, M.; Rayamajhi, S. Planning a system of permanent sample plots for integrated long-term studies of community-based forest management. Bank. Janakari 2006, 16, 3-11. [CrossRef]

24. Sunam, R.K.; Paudel, N.S.; Paudel, G. Community forestry and the threat of recentralization in Nepal: Contesting the bureaucratic hegemony in policy process. Soc. Nat. Resour. 2013, 26, 1407-1421. [CrossRef]

25. GoN. Community Forest Product Collection and Sale Directive; Government of Nepal (GoN): Kathmandu, Nepal, 2014.

26. GoN. Forest Act; Government of Nepal (GoN): Kathmandu, Nepal, 1993.

27. GoN. Forest Regulation, 2051; Government of Nepal (GoN): Kathmandu, Nepal, 1995.

28. DoF. Guideline for Inventory of Community Forestry; Department of Forests (DoF): Kathmandu, Nepal, 2000.

29. DoF. Community Forest Inventory Guideline; Department of Forests (DoF): Kathmandu, Nepal, 2004.

30. DoF. Circular Issued on 30th September; Department of Forests (DoF): Kathmandu, Nepal, 2012.

31. DoF. Scientific Forest Management Directive; Department of Forests (DoF): Kathmandu, Nepal, 2014.

32. KCFUG. Forest Management Plan; Kankali Community Forest User Groups (KCFUG): Khairahani, Nepal, 2013.

33. Müller, W.G. Collecting Spatial Data: Optimum Design of Experiments for Random Fields; Springer: New York, NY, USA, 2001.

34. Puri, L.; Meilby, H.; Rayamajhi, S.; Timilsina, Y.P.; Gautam, N.P.; Subedi, R.; Larsen, H.O. Growth and volume based on permanent sample plots in forests managed by communities. Bank. Janakari 2012, 22, 11-18. [CrossRef]

35. Devkota, R.R. Interests and Power as Drivers of Community Forestry: A Case Study of Nepal; Universitätsverlag Göttingen: Göttingen, Germany, 2010; pp. 1-348.

36. Tian, N.; Poudyal, N.C.; Lu, F. Understanding landowners' interest and willingness to participate in forest certification program in China. Land Use Policy 2018, 71, 271-280. [CrossRef]

37. Nightingale, A.J. The experts taught us all we know: Professionalisation and knowledge in Nepalese community forestry. Antipode 2005, 37, 581-603. [CrossRef]

38. Ojha, H.R.; Khatri, D.B.; Shrestha, K.K.; Bhattarai, B.; Baral, J.C.; Basnett, B.S.; Goutam, K.; Sunam, R.; Banjade, M.R.; Jana, S.; et al. Can evidence and voice influence policy? A critical assessment of Nepal's forestry sector strategy. Soc. Nat. Resour. 2014, 29, 357-373. 
39. Bhattacharya, A.K.; Basnyat, B. An analytical study of operational plan and constitutions at western terai region of Nepal. Bank. Jankari 2003, 13, 3-14.

40. Yadav, N.; Yadav, K.; Yadav, K.; Thapa, N. Facilitating the transition from passive to active facilitating transition from passive to active management of community forests in Nepal. J. For. Livelihood 2009, 8, 51-66. [CrossRef]

41. Cerutti, P.O.; Nasi, R.; Tacconi, L. Sustainable forest management in Cameroon needs more than approved forest management plans. Ecol. Soc. 2008, 13, 36. [CrossRef]

42. Gilmour, D. Silviculture and community forestry: Looking backwards, looking forwards. Bank. Janakari 2018, 4, 6-14. [CrossRef]

43. Subedi, V.R.; Bhatta, K.D.; Poudel, I.P.; Bhattarai, P. Application of silvicultural system, yield regulation and thinning practices in natural forests: Case study from western Terai. Bank. Janakari 2018, 4, 91-97. [CrossRef]

44. Cedamon, E.; Nuberg, I.; Paudel, G.; Basyal, M.; Shrestha, K.; Paudel, N. Rapid Silviculture Appraisal to Characterize Stand and Determine Silviculture Priorities of Community Forests in Nepal. Small-Scale For. 2016, 16, 195-218. [CrossRef]

45. Ojha, H.; Bhattarai, B. Understanding community perspectives of silvicultural practices in the middle hills of Nepal. For. Trees People Newsl. 2001, 40, 55-61.

46. Sapkota, I.P.; Tigabu, M.; Odén, P.C. Spatial distribution, advanced regeneration and stand structure of Nepalese Sal (Shorea robusta) forests subject to disturbances of different intensities. For. Ecol. Manag. 2009, 257, 1966-1975. [CrossRef]

47. Gottesman, A.J.; Keeton, W.S. Regeneration responses to management for old-growth characteristics in northern hardwood-conifer forests. Forests 2017, 8, 45. [CrossRef]

(C) 2018 by the authors. Licensee MDPI, Basel, Switzerland. This article is an open access article distributed under the terms and conditions of the Creative Commons Attribution (CC BY) license (http:/ / creativecommons.org/licenses/by/4.0/). 